Revista de Psicología y Educación / Journal of Psychology and Education, 2022, 17(1), 54-68 (www.rpye.es)

\title{
Meditation practice: A Welcome Activity in a Pre-service Teacher Education Program during Pandemic
}

\author{
Laura Margarita Daza-Murcia \\ Universidad Industrial de Santander, Colombia
}

\begin{abstract}
Emergency Remote Teaching, ERT, was the instruction modality adopted by universities to face social distancing generated by the Covid-19 pandemic. This sudden adjustment mostly affected undergraduate students from an English as a Foreign Language (EFL) pre-service teacher education program offered at a public university in Colombia, who expressed having felt challenged, sad, disappointed, uncomfortable, and anxious before the virtual lectures began. For this reason, a Meditation practice was implemented as a welcome activity in three different Pedagogy courses during the first 2020 academic semester. Thus, this mixed study analyzed the effects of the Meditation practice from the students' perspective. The participants were 74 undergraduates, with an age range between 18 and 25 years $(M=20.33)$. The data was gathered through two semi-structured online surveys and a Semantic Differential Scale with two questions. The qualitative data were studied following the Grounded Theory, whereas the quantitative data were analyzed according to the emotional reactions in the activity scale. Final results identified the following effects of the Meditation practice: inner peace, readiness to learn, strong focus, mental health, innovation, comfort with ERT, and empathy. It can be concluded that the Meditation practice had positive effects on students' attitude towards ERT.

Keywords: Meditation practice, Higher education, Welcome Activity, Emergency Remote Teaching.
\end{abstract}

\section{La meditación: una actividad de bienvenida implementada en un programa de licenciatura durante la pandemia}

Resumen: La modalidad de instrucción adoptada por las universidades para enfrentar la pandemia del Covid-19 fue la enseñanza remota de emergencia, ERT por sus siglas en inglés. Este ajuste afectó a los estudiantes de un programa de licenciatura en lenguas extranjeras de una universidad pública colombiana, quienes al iniciar la virtualidad expresaron haberse sentido retados, tristes, decepcionados, incómodos y ansiosos. Por esta razón, la meditación se implementó como una actividad de bienvenida en tres cursos de pedagogía durante el primer semestre académico del año 2020. Esta investigación mixta analizó los efectos de la meditación desde la perspectiva de los estudiantes. Los participantes fueron 74 estudiantes de pregrado con un rango de edad entre 18 y 25 años $(M=20.33)$. La información se recolectó a través de dos encuestas semiestructuradas virtuales y una escala Semántica Diferencial. Los datos cualitativos se estudiaron en relación con la Teoría Fundamentada, mientras que los cuantitativos se analizaron de acuerdo a las reacciones en la escala de actividad. Como efectos de la meditación se identificaron: paz interior, disposición para aprender, concentración, salud mental, innovación, comodidad con ERT y empatía. Así, se concluyó que la meditación tuvo efectos positivos en la actitud de los estudiantes hacia ERT.

Palabras clave: Práctica de Meditación, Educación Superior, Actividad de Bienvenida, Enseñanza Remota de Emergencia.

Due to the Coronavirus pandemic, universities worldwide had to switch their way of delivering on-campus courses from the

Recibido: 24/08/2021 - Aceptado: 03/01/2022 - Avance online:15/01/2022 *Correspondencia: Laura Margarita Daza-Murcia

Universidad Industrial de Santander, Bucaramanga, Colombia Dirección: Carrera 32\# 1 10-40. 68000, Bucaramanga, Colombia.

E-mail: Imdazamu@correo.vis.edu.co traditional classroom, face-to-face setting to online meetings held from home (Shim and Lee, 2020) as product of Emergency Remote Teaching (ERT) (Hodges et al., 2020). An example of this change in instruction modality took place in a public Colombian university where the first academic period of 2020 
started abruptly by using ERT without offering any kind of emotional support to students.

As learners' feelings are crucial in their learning process (Zull, 2002), the fact of having zero emotional assistance from the university before starting the first academic semester of the year 2020, identified as period 2020-1, affected the participants of the present study. Facing new experiences or having to adapt to abrupt changes can provoke an emotional burden on people who go through them (Brenner, 2014). Moreover, leaving the comfort zone without a smooth transition can alter success in life when people do not have a growth mindset (Dweck, 2006). As undergraduate programs in Colombia are mainly taught on campus, the experience of studying online was a first-time event that made students feel vulnerable because they were out of the comfort zone.

Since the use of ERT is considered a huge emotional challenge for learners (Ohashi, 2020), the plan of expressing empathy with a group of undergraduate students, from an EFL teaching program, was the driven idea to implement the MP as a welcome activity. This type of exercise has proven to be an accurate choice to empathize with undergraduates, as Manocha (2000) pointed out, "meditation can be an effective form of stress reduction and has the potential to improve quality of life" (p. $1138)$.

Thus, this study illustrates the spiral process of an action research, where the researcher recognized that students needed empathy to have a smooth transition from face-to-face to virtual classes. For this reason, the leading question of this study was: What are the possible effects of implementing the MP as a welcome activity during ERT on undergraduate students from an EFL teaching program?

To answer this inquiry, the following was set as the main objective: to analyze the possible effects of implementing the MP as a welcome activity during ERT in an EFL teaching program by examining the following:
1) the students' feelings about ERT, and 2) the students' assumptions, emotional reactions and perceptions about the MP.

Consequently, this study describes the pedagogical implementation of the MP within a higher education context, which includes the material used and the steps followed by the teacher-researcher. In addition, this study presents the effects of this pedagogical implementation based on the participants' perceptions.

Moreover, the present study could be one of the first registered of this kind in Colombia, since studies about MPs in Colombian higher education contexts during ERT were not found in the relevant literature.

\section{THEORETICAL FRAMEWORK}

\section{EMERGENCY REMOTE TEACHING}

Emergency remote teaching (ERT) arose as a provisional solution to the global lockdown caused by the Coronavirus pandemic crisis. This type of instruction modality replaced the in-person classes temporarily in order to avoid interrupting the teaching and learning process placed in educational institutions (Hodges et al., 2020). ERT is characterized by synchronous virtual meetings using online resources to deliver classes, adapting content, material and teaching strategies. Unfortunately, quality is not a recognized attribute of this teaching mode due to improvisation (Hodges et al., 2020).

Besides, in some American schools, implementing ERT was demanding for 325 K-12 teachers as they were not ready neither to teach online nor to use technological tools in their classes (Trust and Whalen, 2020). According to Ferri et al., (2020), the information gathered through the use of an online discussion forum allowed them to identify that students and teachers from Portugal, the United Kingdom (UK) Italy, Estonia, Slovakia, Lebanon and Hungary had to deal with various technological, pedagogical and social 
difficulties. Moreover, 341 university teachers and lectures of all educational levels in Mexico had issues with adequate equipment, familiarity with digital tools, time management, stress management and teachers' new socioeconomic situation (Zapata-Garibay et al., 2021).

On the other hand, initiatives to improve this instructional modality have become noticeable. Huang et al., (2020), for instance, suggested interventions from specialists, educational institutions and government to support teachers, learners and families in order to ensure a productive online learning environment based on the Chinese experience during the Covid-19 pandemic. Additionally, the opportunity to be more open to implementing new learning contexts such as online, blended and remote modalities in higher education has been made visible to the world (Ali, 2020). Moreover, Grandits and Wagle (2021) recommended profound determination from teachers to reduce the inequities uncovered during the pandemic by engaging students to succeed during ERT.

\section{FEELINGS IN THE LEARNING PROCESS}

As stated by Zull (2002) "feelings always affect reasoning and memory" (p. 86), which are two of the main brain functions which provide room for learning. For Saville-Troike (2006) bearing in mind students' emotions, attitudes, motivation and anxiety levels is crucial in the learning process. Therefore, fostering hopeful emotions in the class and creating a positive learning atmosphere are some of the teachers' purposes to decrease negative feelings that can hinder the learning process (Pekrun,2014).

According to Parra (2019) acknowledging students' feelings entails recognizing their existence, which establishes bonds between educators and learners that go beyond just teaching and learning content. Moreover, the Monitor Model, proposed by Krashen (1978) recommends to decrease the level of the affective filter before presenting input, otherwise it will not be processed correctly. Therefore, students need to feel motivated, confident, safe and heard to be able to learn.
However, learning is, in fact, a learner's decision. Educators ought to design an effective learning environment to facilitate this process. Kumaravadivelu (2003) pointed out that "the success of the attempt is, of course, dependent on their learners' willing cooperation to make use of the conditions that have been created" (p. 44). For this reason, students' feelings and attitudes towards the class are highly relevant for learning during the teaching time.

\section{MEDITATION}

As claimed by Levete (2001), meditation has been implemented for a long time by many different cultures around the world. The main reason for meditating is related to how vital it is for human beings' spiritual life. Additionally, meditation is a formal exercise that relaxes the mind by focusing on the person, their mind and their surroundings. According to Behan (2020), there exist different meditation techniques, however, they all share a core intention, namely, drawing one's attention to the present moment and reacting with equanimity to every life situation. Thus, meditation practice can help decrease anxiety levels, depression and pain.

Meditation reduces stress because it helps to leave everyday concerns behind to concentrate on "the here and now". In fact, Manocha (2000, p. 1136) suggested that "authentic meditation enables one to focus on the present moment rather than dwell on the unchangeable past or undetermined future". Also, Ramsburg and Youmans (2013), in their research with students from the Introduction to Psychology course in the California state University, proved that having short periods of meditation before lectures improves the ability to retain information. This means that meditation practice can affect students' cognitive skills positively.

Eventually, meditation and education could be considered as two similar practices. As long as both share their main purpose: to provide space for a healthy mind and heart, where students can fulfill their intellectual, emotional and physical needs (Erricker, 2001). Hence, these two practices could work together very 
well to contribute to the process of building healthy human beings.

\section{METHOD}

From a pragmatic worldview (Creswell, 2014), the present study is contemplated as a mixed action research. In the mixed approach, qualitative and quantitative data is collected, studied and linked to provide a solution for the stated problem (Hernández et al., 2006). Besides, action research is carried out to find means to upgrade the teaching practice and therefore, to construct knowledge around the learning process (Mcniff, and Whitehead, 2010) by proposing and making adjustments (Newby, 2014).

Action research has four basic steps: "1Identifying the research problem or question, 2- Obtaining the necessary information to answer the question(s), 3- Analyzing and interpreting the information that has been gathered, and 4- Developing a plan of action" (Fraenkel and Wallen, 2008, p.592).

\section{PARTICIPANTS}

The participants were 74 undergraduate students (44 female and 30 male), with an age range of 18 to 25 years old $(M=20.33)$ (SD $=0.41$ ), who were enrolled in one of the three courses where the implementation took place; Learning and pedagogical models, Critical pedagogy and post-structuralism and English didactics. These three courses are part of the pedagogy component of an EFL teaching program in a public Colombian university, as described in Table 1.

The participants belonged to different academic levels. And not only did they participate in the study but they also were the teacher-researcher's students. This sample is considered a non-probability convenience sample because this type of sampling implies selecting a group the researcher already knows to act as participants, as they are deemed to have a high possibility to engage (Cohen et al., 2007).

\section{DATA COLLECTION INSTRUMENTS}

In this study, two semi-structured online surveys were conducted to collect qualitative data, and a Semantic Differential Scale with two questions was used to gather quantitative data (See Appendix 1). The information was obtained using an Electronic Survey Method through Google Forms (Andrews et al., 2003). All 74 participants answered the 3 data collection instruments. The instruments' aims and moments are explained in Table 2.

The qualitative data were analyzed following the procedures of Grounded Theory (Charmaz, 2006). Students' feelings, assumptions and perceptions about the MP were recorded, organized and categorized. While the quantitative data were examined according to the significance of the bipolar adjectives (Calm - Anxious) in the activity scale of the Semantic Differential Scale (Osgood at al., 1957), which was mainly used to obtain information related

Table 1

Pedagogy courses information

\begin{tabular}{|c|c|c|c|}
\hline Pedagogy course & Level & $\begin{array}{c}\text { Undergraduate } \\
\text { students enrolled }\end{array}$ & Classes a week \\
\hline Learning and Pedagogical models & 3rd semester & 34 & 1 \\
\hline Critical Pedagogy and Post-structuralism & 4th semester & 25 & 2 \\
\hline English Didactics & 5th semester & 15 & 2 \\
\hline
\end{tabular}


Table 2

Data collection instruments information

\begin{tabular}{|c|c|c|c|}
\hline Instrument & Objective & $\begin{array}{c}\text { Number of } \\
\text { questions }\end{array}$ & Moment \\
\hline Semi-structured online survey 1 & $\begin{array}{c}\text { To explore participants' feelings about ERT } \\
\text { and assumptions about the Meditation } \\
\text { practice before its implementation. }\end{array}$ & $\begin{array}{c}\text { Before starting the } \\
\text { Meditation practice } \\
\text { implementation }\end{array}$ \\
\hline Semantic Differential Scale & $\begin{array}{c}\text { To recognize participants' emotional } \\
\text { reactions before and after the Meditation } \\
\text { practice implementation }\end{array}$ & 2 & $\begin{array}{c}\text { Meditation practice } \\
\text { implementation }\end{array}$ \\
\hline Semi-structured online survey 2 & $\begin{array}{c}\text { Last week of the } \\
\text { To interpret participants' perceptions } \\
\text { after the whole implementation }\end{array}$ & 1 & 2 \\
\hline
\end{tabular}

to the participants' emotional reactions before and after the MP implementation. These two kinds of data were integrated (Tashakkori and Creswell, 2007), and a single report with findings and conclusions is presented.

\section{PEDAGOGICAL INTERVENTION}

The MP was a welcome activity implemented by the teacher-researcher in charge of the three pedagogy courses previously mentioned (Learning and pedagogical models, Critical pedagogy and post-structuralism, and English didactics). It is important to highlight that this same person also collected the data and, subsequently, analyzed this information gathered.

The meditation practice was carried out during the usage of ERT in the 20201 academic semester of an EFL teaching program offered at a public university in Colombia. The main purpose of this practice was to generate an optimal learning atmosphere in the critical moment of facing an abrupt change in instructional mode. Then, the MP's principal characteristic was the use of meditation videos at the beginning of every single class. The reason behind using videos as central instruments in this pedagogical intervention was the principle of practicality, as the classes of the 2020-1 academic period were delivered using computers, and distance between teacher and students was the main feature of virtuality.

The videos were selected according to the following criteria: 1) Youtube public videos, 2) they would be 5 to 7 minutes long, 3) in English, and 4) with a guiding voice. 15 videos in total were chosen from 12 different YouTube channels (see Table 3). Then, after the 15th lesson, the videos were repeated.

Regarding the MP's routine, it contained 9 basic steps that were followed before, during and after the MP's implementation: steps 1 to 6 refer to the before stage, step 7 refers to the during stage; and steps 8 and 9 were called the after stage. Figure 1 explains the $M P^{\prime} s$ routine in detail.

\section{RESULTS}

Students' feelings about ERT and assumptions about the Meditation practice before its implementation were gathered through an online survey which contained 2 open-ended questions., whose answers were analyzed according to Grounded Theory (Charmaz, 2006). In accordance with question (1) How did you feel when you knew that ERT was going to be the teaching mode for 2020 1? Why? The two emerging categories were: positive and negative feelings towards ERT. In Table 4, the codes and subcategories are detailed. 
Table 3

Information about the YouTube channels and videos used in the MP implementation

\begin{tabular}{|c|c|c|}
\hline YouTube channel & Videos per channel & Videos \\
\hline Beyond purpose & 1 & $\begin{array}{l}\text { 1- The five-minute miracle - Daily guided } \\
\text { meditation }\end{array}$ \\
\hline Mindfulpeace & 2 & $\begin{array}{l}\text { 2- } 5 \text { Minute Breathing Exercise - Guided } \\
\text { Mindfulness Meditation 4K -Calming } \\
\text { anxiety reduction } \\
\text { 3- } 5 \text { Minute Quick Anxiety Reduction - } \\
\text { Guided Mindfulness Meditation }\end{array}$ \\
\hline The Honest Guys - Meditations - Relaxation & 2 & $\begin{array}{l}\text { 4- } 5 \text { MINUTE Calming Meditation (With } \\
\text { Guiding Voice) } \\
\text { 5- } 5 \text { Minute Stress Relief Guided Meditation }\end{array}$ \\
\hline $\begin{array}{c}\text { Jason Stephenson - Sleep Meditation } \\
\text { Music }\end{array}$ & 1 & 6- POSITIVE MIND in 5 Minutes Meditation \\
\hline My Peace Of Mindfulness & 1 & $\begin{array}{l}\text { 7- } 5 \text { Minute Guided Meditation For Positive } \\
\text { Energy \& Thinking }\end{array}$ \\
\hline Teni Meditations \& Workouts & 1 & $\begin{array}{l}\text { 8- } 5 \text { Minute Guided Meditation | The } \\
\text { Future YOU }\end{array}$ \\
\hline Soul Calm - Relaxing Nature \& Meditations & 2 & $\begin{array}{l}\text { 9- Guided Meditation (Stress \& Anxiety } \\
\qquad \text { Relief -5 minutes) } \\
\text { 10- Guided Meditation Beach (5 minutes } \\
\text { to Inner Calm) }\end{array}$ \\
\hline Maria Lewis & 1 & $\begin{array}{l}\text { 11- Mindfulness Guided Meditation - } 5 \\
\text { Minutes }\end{array}$ \\
\hline The Mindful Movement & 1 & $\begin{array}{l}\text { 12- Short Calming Mindfulness Meditation } \\
\text { to Clear the Clutter in your Mind / Mindful } \\
\text { Movement }\end{array}$ \\
\hline Meditation Vacation & 1 & $\begin{array}{l}\text { 13- } 5 \text { min clearing morning Guided } \\
\text { meditation for positivity and grounding }\end{array}$ \\
\hline Iman & 1 & $\begin{array}{l}\text { 14- } 5 \text { Minute Guided Meditation on Being } \\
\text { Present - Featured on RVIVE }\end{array}$ \\
\hline Goodful & 1 & $\begin{array}{l}\text { 15- 5-Minute Meditation You Can Do } \\
\text { Anywhere }\end{array}$ \\
\hline
\end{tabular}




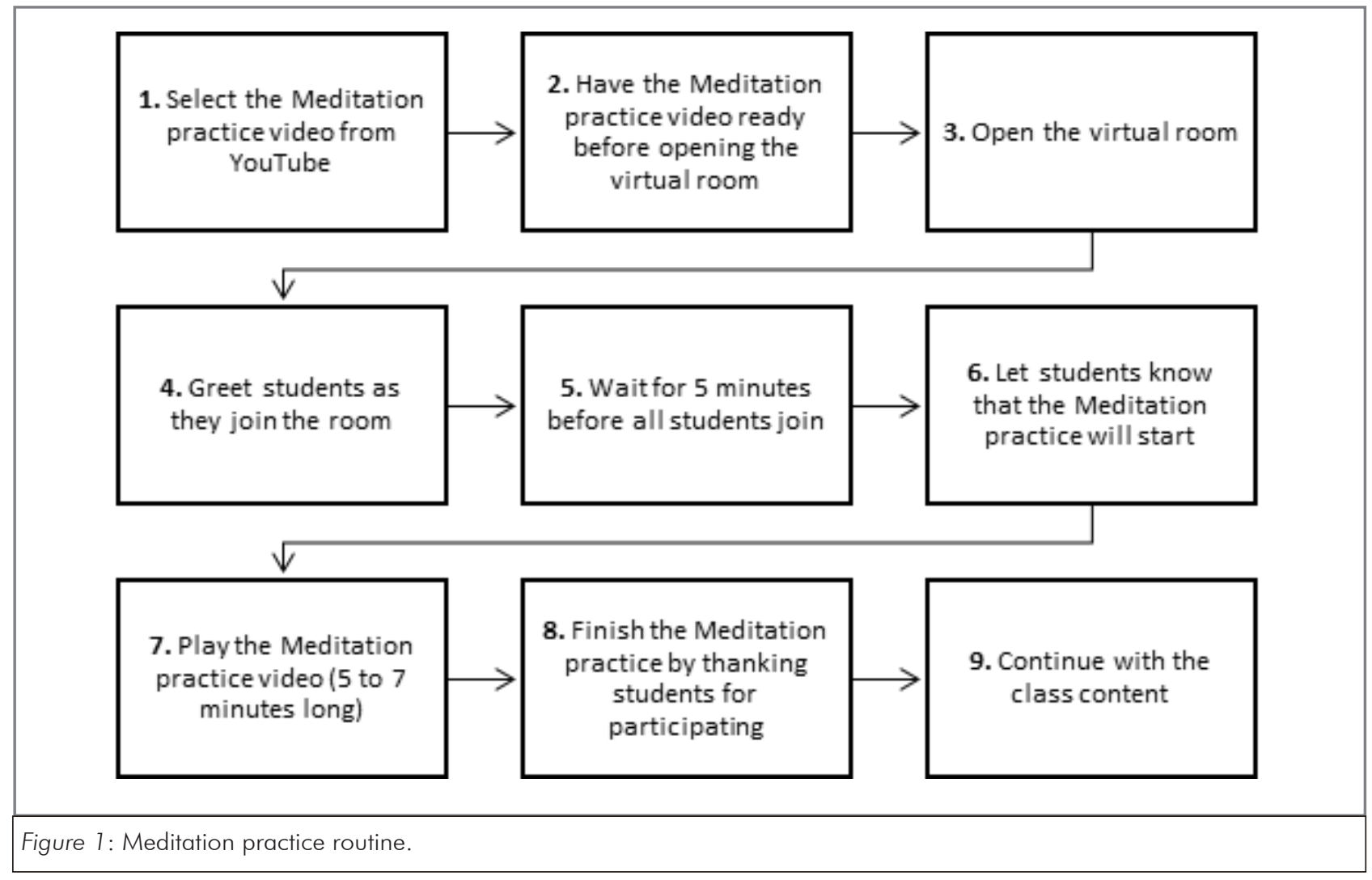

\begin{tabular}{|c|}
\hline Table 4 \\
Codes, subcategories and categories emerged from the online survey 1 - Question 1 \\
\hline
\end{tabular}

\begin{tabular}{|c|c|c|}
\hline Codes & Subcategories & Category \\
\hline $\begin{array}{l}\text { A new enriching experience } \\
\text { A new semester no matter the teaching mode }\end{array}$ & Excited & \multirow[t]{2}{*}{ Positive feelings towards ERT } \\
\hline $\begin{array}{l}\text { Easier to understand in online classes } \\
\text { All day at home } \\
\text { No wasted time commuting }\end{array}$ & Comfortable & \\
\hline $\begin{array}{l}\text { A new way to learn } \\
\text { A new teaching method } \\
\text { All-day-long in front of the screen } \\
\text { Technology difficulties } \\
\text { More distractions at home } \\
\text { Lack of concentration }\end{array}$ & Challenged & \multirow[t]{5}{*}{ Negative feelings towards ERT } \\
\hline $\begin{array}{l}\text { Lack of social interaction } \\
\text { Solitude at home }\end{array}$ & $\begin{array}{c}\text { Sad } \\
\text { Disappointed }\end{array}$ & \\
\hline \multicolumn{2}{|l|}{$\begin{array}{c}\text { No limits between personal life and academic life } \\
\text { No appealing to this teaching mode } \\
\text { Money issues }\end{array}$} & \\
\hline $\begin{array}{l}\text { No good internet connection } \\
\text { No good PC } \\
\text { Not enough technological tools at home }\end{array}$ & $\begin{array}{l}\text { Uncomfortable } \\
\text { Anxious }\end{array}$ & \\
\hline $\begin{array}{l}\text { Harder to understand in online classes } \\
\text { Not all are supportive teachers } \\
\text { An unexpected and first-time experience } \\
\text { The quality of education would be affected } \\
\text { Awkward learning environment }\end{array}$ & & \\
\hline
\end{tabular}


These results suggest that more negative feelings towards ERT were experienced by participants, as 56 of them, (75.6\%), mentioned having felt "challenged", "sad", "disappointed", "uncomfortable" and "anxious". While 18 of the participants, (24.4\%), highlighted just two positive feelings: "excitement" and "comfort". Examples of the negative feelings towards ERT are supported by excerpts 1, 2, 3, 4, 5 and 6 below:

I felt sad because I'm not used to this and I hated the idea of not seeing my friends (Excerpt 1, participant 4, online survey 1, question 1).

I was disappointed because I felt like I wasn't going to have any limits between my personal space and study (Excerpt 2, participant 8 , online survey 1 , question 1).

I felt challenged because is something abnormal, our curriculum is like so hard to be taught in this way, I think (Excerpt 3, participant 18, online survey 1 , question 1).

Challenged because it is not the same thing that in person, it is more tiring, you literally are the whole day sitting in front of your computer (Excerpt 6, participant 34, online survey 1 , question 1).

Really uncomfortable since at that moment I didn't have a good internet connection nor a good PC for the classes (Excerpt 4, participant 24, online survey 1, question 1).
I was anxious because it was a new experience and I didn't know how it was going to affect the quality of education (Excerpt 5, participant 29, online survey 1, question 1).

On the other hand, excerpts 7, 8 and 9 are examples of the positive feelings participants had towards ERT: "excitement" and "comfort".

I was really excited because it was going to be a new experience for me that could enrich my life (Excerpt 7, participant 3, online survey 1, question 1).

Super comfortable because I think it's easier for me to understand the topics we learn, I distract less during the classes and I feel like I can manage my time in the best way possible (Excerpt 8, participant 5, online survey 1, question 1).

Comfortable because I've always thought that we lose a lot of time commuting to university, I hate the transport system here, so I was excited that I could go to class in the comfort of my house and that I did not have to worry about traffic, noises, pollution, etc. (Excerpt 9, participant 23, online survey 1, question 1).

The survey's second question, "Which do you think could be the effects of the Meditation practice during the usage of ERT?", drew a unique emerging category, which was called beneficial effects. Codes and subcategories are shown in Table 5 .

Table 5

Codes, subcategories and categories emerged from the online survey 1 - Question 2

\begin{tabular}{|c|c|c|}
\hline Code & Subcategory & Category \\
\hline $\begin{array}{c}\text { Breathing to forget negative situations } \\
\text { Clear and organized mind } \\
\text { Less stress }\end{array}$ & Bnner peace & \\
\hline $\begin{array}{c}\text { Willingness to learn } \\
\text { Engagement with the class } \\
\text { Positive attitude towards the class } \\
\text { More remembrance }\end{array}$ & Readiness to learn \\
\hline $\begin{array}{c}\text { Better concentration during classes } \\
\text { More focus when studying }\end{array}$ & Strong focus \\
\hline Awareness of personal emotions \\
Well being
\end{tabular}


These findings indicate that $100 \%$ of the participants believed that Meditation practice was likely to have beneficial consequences during ERT use. Participants mentioned inner peace, readiness to learn, strong focus and mental health as possible benefits. Excerpts $10,11,12,13,14$ and 15 exemplify the potential Meditation practice effects:

Meditation helps to have mental peace so you forget some problems and you focus on your breathing and then in the online learning process (Excerpt 10, participant 46 , online survey 1 , question 2 ).

Mindfulness is a wonderful technique that will help us to be aware of our emotions. Also, it will be great for our psychological health (Excerpt 11, participant 48, online survey 1, question 2).

Meditation can help us to clear and focus our mind before classes, also to improve our concentration in the course of the class (Excerpt 12, participant 53, online survey 1, question 2).

It'll help me to be fully engaged in the class, to be focused in it. Meditation practice will also help me to relieve the anxiety I could feel before or maybe during classes. And, it could help me be more creative (Excerpt 13, participant 57, online survey 1 , question 2 ).
I have heard that meditation is good for your body and your mind and it helps you to feel in a state of wellness (Excerpt 14, participant 66, online survey 1, question 2).

If we meditate, we can associate our topics learned by remembering our Meditation practice (Excerpt 15, participant 74, online survey 1, question 2).

In light of online survey 1's results, participants had more negative feelings towards ERT than positive ones (they felt "challenged", "sad", "disappointed", "uncomfortable" and anxious" vs "excited" and "comfortable"). Besides, students assumed that the MP could have beneficial effects such as "inner peace", "readiness to learn", "strong focus" and "mental health during ERT use".

In addition, participants' emotional reactions before and after the Meditation practice activity were studied using a Semantic Differential Scale (Osgood et al., 1957). Which had the following two questions: (1) How did you feel BEFORE starting the class with the Meditation practice? (2) How did you feel AFTER having the Meditation practice?

The opposite adjectives in the scale were: Calm and Anxious.

Through the use of this instrument the researcher gathered the quantitative information offered in Table 6.

Table 6

Participants' emotional reactions based on the Semantic Differential Scale results

\begin{tabular}{|c|c|c|c|}
\hline Emotional reaction & $\begin{array}{c}\text { Before the Meditation } \\
\text { practice }\end{array}$ & $\begin{array}{c}\text { After the Meditation } \\
\text { practice }\end{array}$ & $\begin{array}{c}\text { Difference between before } \\
\text { and after the Meditation } \\
\text { practice }\end{array}$ \\
\hline Very anxious & $13 \%$ & $2 \%$ & $-11 \%$ \\
\hline A little anxious & $44 \%$ & $3 \%$ & $-41 \%$ \\
\hline Neither anxious nor calm & $31 \%$ & $11 \%$ & $20 \%$ \\
\hline A little calm & $9 \%$ & $41 \%$ & $+32 \%$ \\
\hline Very calm & $3 \%$ & $43 \%$ & $+40 \%$ \\
\hline
\end{tabular}


As it can be read in Table 6, the number of students feeling "a little anxious" was higher than those who reported feeling "a little calm" before the MP. While, after the MP video, the trend was the opposite, as there were more participants feeling "very calm" than "very anxious". The differences in the anxiety level of the participants between the "before" and the "after" allow to see the effectiveness in terms of emotional reactions that the MP had, since anxiety dropped by $52 \%$ after it and the sense of calmness increased $72 \%$.

These results suggest that the MP implementation contributed to reduce significantly the levels of anxiety and promoted calmness during ERT.

Finally, participants' perceptions about the MP effects after the implementation were explored using the online survey 2 , which had one open-ended question: (1) "According to your experience, which effects had the MP during the use of ERT?" This question drew a unique emerging category called beneficial effects.
Table 7 illustrates codes and subcategories.

These results demonstrate that 100\% of the participants perceived MP's effects as beneficial. Among the benefits, participants mentioned feeling: "inner peace", "readiness to learn", "strong focus", "mental health", "innovative practice", "comfort with ERT" and "teacher's empathy". The last three mentioned (innovative practice, comfort with ERT and teachers' empathy) are different from the benefits participants assumed before the intervention took place. Excerpts 16, 17, 18, $19,20,21$ and 22 support the aforementioned subcategories:

It helped me to stop and slow the rhythm of the day, rewind it and start it again with less stress, bad feelings and thoughts. It helped me to relax a lot (Excerpt 16, participant 4, online survey 2 ).

From my point of view and what I have learned, when we have a good attitude and we are relaxed, we process the information

Table 7

Codes, subcategories and categories emerged from the online survey 2 - Question 1

\begin{tabular}{|c|c|c|}
\hline Codes & Subcategories & Categories \\
\hline $\begin{array}{c}\text { Reduction of anxiety levels } \\
\text { High relaxation level } \\
\text { Clear thoughts }\end{array}$ & Inner peace & \multirow[t]{7}{*}{ Beneficial effects } \\
\hline $\begin{array}{l}\text { More participation during the class } \\
\text { More learning and remembrance } \\
\text { Positive learning environment } \\
\text { Determination to learn } \\
\text { Engagement with the class } \\
\text { Effective learning process } \\
\text { Willingness to learn }\end{array}$ & Readiness to learn & \\
\hline $\begin{array}{l}\text { Mindfulness } \\
\text { Better concentration during the class }\end{array}$ & Strong focus & \\
\hline $\begin{array}{l}\text { Self-reflection } \\
\text { Positive attitude towards life } \\
\text { Mental health awareness }\end{array}$ & Mental health & \\
\hline $\begin{array}{l}\text { Happiness to do something new } \\
\text { Usefulness for other academic activities } \\
\text { Interest to use Meditation practice in professional life }\end{array}$ & Innovative practice & \\
\hline Positive attitude towards ERT & Comfort with ERT & \\
\hline Feeling loved and cared & Teacher's empathy & \\
\hline
\end{tabular}


better and we really learn (Excerpt 17, participant 7 , online survey 2 ).

Meditation practice let me stop thinking about my problems and the other subjects, I was just concentrating on the topics my teacher and partners were presenting (Excerpt 18, participant 26, online survey 2).

After the short Meditation practice session, I felt better inside my body and my day turned different, in a good way. Also, it helped me realize the importance of my mental health (Excerpt 19, participant 28, online survey 2).

I think that now I can implement this practice for future classes or for future situations where I have to manage stress or anxiety, when I become a teacher (Excerpt 20 , participant 42 , online survey 2 ).

Right now, the effect is bigger... Right now, that impact is bigger, because personally, remote learning is not for me, and the meditation practice made it feel cool, comfortable, like a real new and exciting adventure (Excerpt 21, participant 16, online survey 2).

The Meditation practice was relaxing and I loved that the teacher thought about us (students) when she decided to include it in the classes (Excerpt 22, participant 38, online survey 2 ).

\section{DISCUSSION}

Creating a positive learning atmosphere with a low affective filter level (Krashen, 1978) where students feel confident, motivated and prepared to learn ought to be one of the aims of education (Kumaravadivelu, 2003). Therefore, pedagogical interventions such as the MP, which in this special case contributed to create a smooth transition from face-to-face to virtual classes while the Covid-19 crisis, are favorable to foster a healthy classroom environment, since students are the center of the learning process. Hence their feelings, dreams and fears are taken into account.

At the beginning of this study, and similar to what Ferri et al., (2020) discovered in their research, students expressed some difficulties in the process of adapting to virtual classes. In fact, some of the participants in the present study manifested having felt: "challenged", "sad", "disappointed", "uncomfortable" and "anxious". However, results of the MP suggest a powerful impact on students' adaptation to ERT, as anxiety levels decreased. This general finding is part of the recommendations advised by Grandits and Wagle (2021) in their study to promote students' success during ERT.

Furthermore, when comparing participants' prior assumptions of the MP effects with the actual effects reported by them after the MP's implementation, four effects appeared in both moments: "inner peace", "readiness to learn", "strong focus" and "mental health", while three new beneficial consequences arose, which were: "innovative practice", "comfort with ERT" and "teacher's empathy". In addition, this last benefit promotes a better teacher-student relationship by letting learners know that they are seen holistically (Parra, 2019). Moreover, students with high levels of concentration have more advantages in their learning process as the memory function is crucial in getting information, knowledge and experience (Zull, 2002).

In addition, participants were conscious of the importance of taking care of their mental health and living in "the here and now" by performing basic but influential activities like the MP (Levete, 2001). Also, students regarded this practice as a useful exercise for their professional life, which is a sign of empathy with their future students as they deemed MP should be replicated when they become teachers. Thus, meditation inside classrooms could contribute to prepare healthier future generations. (Erricker, 2001).

Although it seems that the MP was a great accomplishment, there are some limitations 
to considered in future research. For instance, participants in this study were also the same teacher-researcher's students. Therefore, answers gathered through the use of the data collection instruments could have been affected by the teacher-student relationship.

Another limitation refers to the deficiency in previous research studies on this topic carried out in higher education contexts in Colombia, which generates a gap between what was known and what was expected from this pedagogical intervention.

\section{CONCLUSIONS}

The present mixed action research sought to analyze the possible effects of implementing $M P$ as a welcome activity during ERT in an EFL teaching program by examining: firstly, the students' feelings about ERT, and secondly, the students' assumptions, emotional reactions and perceptions about the MP.

With the aim of gathering participants' feelings about ERT, findings show that more than half of the participants experienced negative feelings such as "sadness", "disappointment", "discontent", "confrontation" and "anxiety" when they knew about it. While just some of the students had the following positive feelings towards ERT: excitement and comfort.

Students' assumptions about the MP prior its implementation were positive towards the practice as all the participants thought it could bring benefits to the ERT classes. The perks cited were: "inner peace", "readiness to learn", "strong focus" "and mental health".

At the end of the pedagogical intervention, the quantitative results obtained from the Semantic Differential Scale indicated that participants' level of anxiety decreased significantly in relation to the way students felt before they had this practice. Besides, the level of calmness increased remarkably in participants.

All the learners identified beneficial effects from this experience in their final impressions.
Among the gains, participants confirmed 4 from the ones they had previously assumed, which were: "inner peace", "readiness to learn", "strong focus" and "mental health". On the other hand, students discovered 3 new benefits: considering the MP as an "innovative practice", feeling "comfortable with ERT" and perceiving "teachers" empathy" in their instructional mode transition.

As a general conclusion, the MP definitely had positive effects on students' attitude towards ERT, as it contributed to reduce their anxiety levels and promoted calmness during this kind of teaching modality. Likewise, and due to the MP, participants could possibly have handled the 2020-1 academic semester more smoothly, which was the first one taught in that way in Colombia.

- Conflict of interest.

The authors declare no conflict of interest.

\section{REFERENCES}

Ali, W. (2020). Online and remote learning in higher education institutes: A necessity in light of COVID-19 pandemic. Higher education studies; 10(3). https://doi. org/10.5539/hes.v10n3pl6

Andrews, D., Nonnecke, B., \& Preece, J. (2003). Electronic survey methodology: A case study in reaching hard to involve internet users. International Journal of Human- computer Interaction, 16(2), 185-210. https://doi.org/10.1207/ S15327590IJHC 160204

Behan, C. (2020). The benefits of meditation and mindfulness practices during times of crisis such as COVID-19. Irish Journal of Psychological Medicine.2020 May 14:13. https://doi:10.1017/ipm.2020.38

Beyond Purpose. (2011, December 29). The five minute miracle - Daily guided meditation [Video]. YouTube. https://www. youtube. com/watch? $v=u t f w-r J U v y 4 \& t=2 \mathrm{~s}$

Brenner, A. (2014, December 30). The first time: 7 things to consider to make your "first" experiences the best they can be. Psychology Today. https:// www.psychologytoday.com/us/blog/influx/201412/the-first-time 
Charmaz, K. (2006). Constructing grounded theory. Thousand Oaks, CA: SAGE Publications.

Cohen, L., Manion, L., \& Morrison, K. (2007). Research methods in education (6th ed.). Routledge/Taylor \& Francis Group.

Creswell, J. W. (2014). Research Design: Qualitative, quantitative, and mixed methods approaches (4th ed.). Thousand Oaks, CA: SAGE Publications.

Dweck, C. S. (2006). Mindset: The new psychology of success. Random House.

Erricker, C. (2001) Meditation and holistic education: the way forward. In Erricker, C. \& Erricker, J. Meditation in schools, a practical guide to calmer classrooms. (pp. 141-144). Continuum International Publishing Group.

Ferri, F., Grifoni, P., \& Guzzo, T. (2020) Online learning and emergency remote teaching: Opportunities and challenges in emergency situations. Societies 2020, 10(4), 86; https://doi.org/10.3390/soc10040086

Fraenkel, J.R. \& Wallen, N.E. (2008) How to design and evaluate research in education. McGraw-Hill.

Goodful. (2019, September 4). 5-minute meditation you can do anywhere [Video]. YouTube. $\quad$ https://www.youtube.com/ watch? $v=$ inpok $4 M K V L M \& t=66 \mathrm{~s}$

Grandits, D., \& Wagle, T. (2021). Making remote learning engaging. Excelsior: leadership in teaching and learning, 13(2), 113-126. https://doi.org/10.14305/ in. 19440413.2021.13.2.03

Hernández Sampieri, R., Fernández-Collado, C., Baptista Lucio, P. (2006). Metodología de la investigación. MC Graw Hill.

Hodges, C., Moore, S., Lockee, B., Trust, T., and Bond, A. (2020, March 27). The difference between emergency remote teaching and online learning. https:// er.educause.edu/articles/2020/3/thedifference-between-emergency-remoteteaching-and-online-learning

Huang, R., Tlili, A., Yang, J., Chang, T-W., Wang, H., Zhuang, R., \& Liv, D. (2020). Handbook on facilitating flexible learning during educational disruption: the Chinese experience in maintaining undisrupted learning in COVID-19 outbreak. https://www.researchgate.net/ publication/339939064 Handbook. on Facilitating Flexible Learning During Educational Disruption The Chinese Experience in Maintaining Undisrupted Learning in COVID-19 Outbreak\#fullTextFileContent

Iman. (2019, May 10). 5 minute guided meditation on being present - Featured on RVIVE [Video]. YouTube. https:// www.youtube.com/watch? $v=B$ jdHrUr5rg\&t=8s

Jason Stephenson - Sleep meditation music. (2016, September 18). Positive mind in 5 minutes meditation. [Video]. YouTube. https://www.youtube.com/ watch? $v=3 R \times X i F g k x G c \& t=1 \mathrm{~s}$

Krashen, S. (1978). The monitor model for second language acquisition. In R.C. Gingras. Second language acquisition and foreign language teaching (pp. 1-26).

Kumaravadivelu, B. (2003). Beyond methods: macrostrategies for language teaching. Yale Language Series.

Levete, G. (2001) Why meditation? In Erricker, C. \& Erricker, J (Eds.), Meditation in schools, a practical guide to calmer classrooms. (pp. 1-23). Continuum.

Lewis, M. [MariaLewis]. (2013, November 3). Mindfulness guided meditation - 5 minutes [Video]. YouTube. https://www.youtube. $\mathrm{com} /$ watch? $\mathrm{v}=\mathrm{dEzbdLn} 2 \mathrm{bJc} \& \mathrm{t}=44 \mathrm{~s}$

Manocha, R. (2000). Why meditation? Australian family physician 29(12):11358. https://www.researchgate.net/ publication/12189441 Why meditation

Mcniff, J. \& Whitehead, J. (2010). You and your action research project. Routledge.

Meditation Vacation. (2018, August 1). 5 min clearing morning guided meditation for positivity and grounding [Video]. YouTube. https://www.youtube.com/ watch? $v=s 9 b 2 y 3 \mathrm{Mg} 2 \mathrm{n} 8 \& \mathrm{t}=145 \mathrm{~s}$

MindfulPeace. (2015, February 25). 5 Minute quick anxiety reduction Guided mindfulness meditation [Video]. YouTube. https://www.youtube.com/ watch? $v=$ MR57rug $8 \mathrm{NsM} \& \mathrm{t}=5 \mathrm{~s}$

MindfulPeace. (2020, May 13). 5 Minute breathing exercise - Guided mindfulness meditation 4K - Calming anxiety reduction [Video]. YouTube. https://www.youtube. $\mathrm{com} /$ watch $\mathrm{v}=$ TXNECalJPDI\& $\mathrm{t}=3 \mathrm{~s}$ 
My Peace of Mindfulness. (2020, March 30). 5 minute guided meditation for positive energy \& thinking [Video]. YouTube. https://www. youtube.com/watch? $v=$ blPWamlibs\&t $=1 \mathrm{~s}$

Newby, P. (2014). Research methods for education. Routledge.

Ohashi, L. (2020, June). Emergency remote teaching: an educational and emotional shift. Mind BrainED Think Tanks. https://www. mindbrained.org/2020/06/emergencyremote-teaching-an-educational-andemotional-shift/

Osgood, C. E., Suci, G. S. \& Tannenbaum, P. $\mathrm{H}$. (1957) The measurement of meaning. Urbana, IL: University of Illinois.

Parra, S.C. (2019). Aprendiendo desde la emoción. Infancias imágenes. 18(2), 285-294 https://doi. org/10.14483/16579089.14532

Pekrun, R. (2014). Emotions and learning. Educational practices Series 24. https://www. iaoed.org/downloads/edu-practices 24 eng.pdf

Ramsburg, J. \& Youmans, R. (2013). Meditation in the higher-education classroom: meditation training improves student knowledge retention during lectures. https://www.researchgate.net/ publication/257795392 Meditation in the Higher-Education Classroom Meditation Training Improves Student Knowledge Retention during Lectures

Saville-Troike, M. (2006). Introducing second language acquisition. Cambridge University Press.

Shim, T. E., \& Lee, S. Y. (2020). College students' experience of emergency remote teaching due to COVID-19. Children and youth services review 119(2). https://doi. org/10.1016/i.childyouth.2020.105578

Soul calm - Relaxing nature \& meditations. (2016, April 23). Guided meditation beach (5 minutes to Inner Calm) [Video]. YouTube. https://www.youtube.com/ watch? $v=Y 7 v O F a 9 y 6 e M \& t=6 s$

Soul calm - Relaxing nature \& meditations. (2016, July 23). Guided meditation (Stress \& anxiety relief -5 minutes) [Video]. YouTube. https://www.youtube.com/ watch? $\mathrm{v}=\mathrm{euQCCs}$ IAsuo
Tashakkori, A., \& Creswell, J. W. (2007). Editorial: The new era of mixed methods. Journal of Mixed Methods Research, 1(1), 3-7. https://doi. org/10.1177/2345678906293042

Teni meditations \& workouts. (2019, December 13). 5 minute guided meditation | The future YOU [Video]. YouTube. https://www.youtube.com/ watch? $\mathrm{V}=\mathrm{HHIXM+82 \textrm {P } E}$

The honest guys - Meditations - Relaxation. (2014, October 7). 5 MINUTE calming meditation (with guiding voice) [Video]. Youtube. https://www.youtube.com/ watch? $v=i 50 Z$ As7v9es\& $=4 \mathrm{~s}$

The honest guys - Meditations - Relaxation. (2019, August 6). 5 minute stress relief guided meditation. [Video]. Youtube. https://www.youtube.com/ watch? $v=\mathrm{L} 1 \mathrm{QOh}-\mathrm{n}$-eus\&t=38s

The mindful movement. (2018, August 13). Short calming mindfulness meditation to clear the clutter in your mind / mindful movement [Video]. Youtube. https:// www.youtube.com/watch? $v=6 \mathrm{kVVrE}$ $s C N A \& t=22 s$

Trust, T. \& Whalen, J. (2020). Should teachers be trained in emergency remote teaching? Lessons learned from the COVID-19 pandemic. Journal of Technology and Teacher Education, 28(2), 189-199. Waynesville, NC USA: Society for information technology \& teacher education. Retrieved May 22, 2021 from https://www.learntechlib.org/ primary/p/215995/.

Zapata-Garibay, R., González-Fagoaga, J.E., González-Fagoaga C.J., Cauich-García, J.R., \& Plascencia-López, I. (2021). Higher education teaching practices experience in Mexico, during the emergency remote teaching implementation due to COVID-19. Front. Educ., 12 March 2021 | https:// doi.org/10.3389/feduc.2021.628158

Zull, J.E. (2002). The art of changing the brain. Sterling, VA: Stylus Publishing, LLC. 


\section{APPENDIX A: DATA COLLECTION INSTRUMENTS}

\section{SEMI-STRUCTURED ONLINE SURVEY 1}

1) How did you feel when you knew that ERT was going to be the teaching mode for 2020 1? Why?

2) Which do you think could be the effects of the Meditation practice during the usage of ERT?

\section{SEMANTIC DIFFERENTIAL SCALE}

1) How did you feel BEFORE starting the class with the Meditation practice?

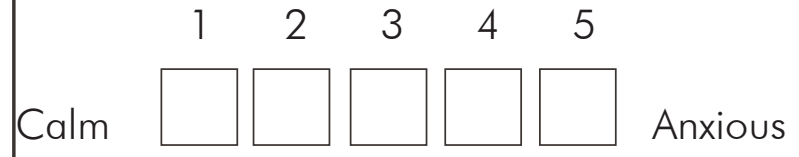

2) How did you feel AFTER having the Meditation practice?

Calm

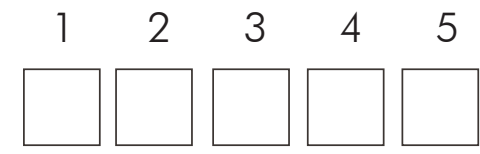
Anxious

\section{SEMI-STRUCTURED ONLINE SURVEY 2}

1) According to your experience, which effects had the Meditation practice during the use of ERT? 